\title{
COVID-19 DAN PENDIDIKAN TINGGI TEOLOGI DI INDONESIA DALAM PERSPEKTIF FILSAFAT PENDIDIKAN TRANSFORMASIONAL
}

\author{
Bakhoh Jatmiko ${ }^{1}$, Ezra Tari ${ }^{2}$, Hengki Wijaya ${ }^{3}$ \\ ${ }^{1}$ Sekolah Tinggi Theologia Nazarene Indonesia \\ ${ }^{2}$ Institut Agama Kristen Negeri Kupang \\ ${ }^{3}$ Sekolah Tinggi Filsafat Jaffray Makassar \\ ${ }^{1} J a l a n$ S ANI, Bokoharjo, Kadisoka, Purwomartani, Kalasan, Sleman, Yogyakarta, Indonesia \\ ${ }_{2}^{2}$ Jalan Cak Doko No. 76, Kampung Baru, Kupang, Nusa Tenggara Timur \\ 3 Jalan G. Merapi 103, Makassar, Sulawesi Selatan \\ Email:djatcair@sttni.ac.id',tariezra@gmail.com², hengkilily1988@gmail.com³
}

\begin{abstract}
ABSTRAK: Covid-19 berdampak pada pendidikan tinggi teologi di Indonesia. Akibat pandemi, pendapatan keuangan kampus mengalami penyusutan. Mahasiswa tidak dapat membayar uang kuliah karena pendapatan orang tua berkurang. Pandemi Covid- 19 menjadi pengalaman yang tidak terprediksi untuk PTKK di Indonesia. Metode yang digunakan penulis adalah kualitatif dengan pendekatan deskriptif. Di dalam tataran praktikal, dalam waktu singkat, PTKK di era ataupun sesudah pandemi wajib beralih bentuk dalam prasarana, finansial serta administrasi, tata cara pengajaran, konten kurikulum (dari teoritis ke misiologis atau efisien), dan kedudukan atau ikatan daya pengajar. PTKK ditantang untuk meninggalkan kerutinan yang tidak relevan, merengkuh cara-cara terkini yang relevan, ataupun mencampurkan keduanya menjadi kombinasi perlengkapan pembelajaran yang lebih efisien.
\end{abstract}

Kata Kunci: covid 19 dan pendidikan teologi; gereja; mahasiswa; ptkk

\section{COVID-19 AND THEOLOGICAL HIGHER EDUCATION IN INDONESIA IN THE PERSPECTIVE OF THE PHILOSOPHY OF TRANSFORMATIONAL EDUCATION}

\begin{abstract}
Covid 19 has an impact on theological higher education in Indonesia. Due to the pandemic, campus financial income has decreased. Students cannot pay tuition fees because their parents' income has been reduced. The Covid-19 pandemic is an unpredicted experience for PTKK (Christian Religion Higher Education) in Indonesia. The method used by the author is qualitative with a descriptive approach. At the practical level, concisely, PTKK, in the era or after the pandemic, should change the forms of infrastructure, finance and administration, teaching procedures, curriculum content (from theoretical to missiological or efficient), and the position or bond of teaching power. PTKK is challenged to leave behind the irrelevant routine, embrace more current and relevant methods, or combine the two for making a more efficient combination of learning tools.
\end{abstract}

Keywords: covid-19 and theological education; church; students; ptke. 


\section{PENDAHULUAN}

Pendidikan Tinggi Keagamaan Kristen (PTKK) merupakan lembaga pendidikan yang memiliki peran penting dalam menghadirkan perubahan bagi individu maupun masyarakat. Landasan yuridis bagi lembaga pendidikan di Indonesia tertuang dalam Undang-undang nomor 20 tahun 2003 (Indonesia, 2003). Undangundang tersebut memberikan mandat kepada setiap lembaga pendidikan untuk berkontribusi dalam menghadirkan perubahan (mencerdaskan) di tengah-tengah masyarakat, berbangsa dan bernegara. Hal ini selaras dengan fungsi pendidikan yang diamanatkan di dalam UUD 1945 pasal 31. Pada hakikatnya, lembaga pendidikan adalah "alat" untuk meningkatkan pengetahuan, keterampilan dan harkat kemanusiaan si pembelajar (Persell, 1979). Tirtarahardja dan La Sasula berpendapat bahwa lembaga pendidikan adalah tempat di mana proses pendidikan (proses transformasi) terjadi, yang secara khusus terdapat tiga lingkungan pembelajaran utama, yaitu keluarga, sekolah dan masyarakat (Tirtarahardja \& Sasula, 2000). Lembaga pendidikan adalah agen pembawa perubahan. Proses transformasi dimungkinkan terjadi karena adanya proses pembelajaran di dalamnya.

Pendidikan bersifat transformatif dan formatif. Sagala menyatakan bahwa pendidikan adalah proses pembentukan (formatif) kemampuan-kemampuan fundamental baik intelektual, maupun emosional, baik individu maupun kelompok (Sagala, 2013). Proses pembelajaran akan menanamkan nilai, keyakinan, norma, pola pikir kepada pembelajar sehingga mereka dapat lebih matang dalam berperilaku di tengah-tengah masyarakat (Lembaga Pendidikan Pengertian, Tujuan, Contoh, Ciri, \& Gambar, n.d.). Prinsip ini membawa pengertian betapa pentingnya peran kualitas pembelajaran yang harus disajikan di setiap lembaga pendidikan. Dasardasar pendidikan harus diletakkan dengan benar.

Selain landasan yuridis, lembaga pen- didikan juga harus memahami landasan filosofis dari pendidikan itu sendiri. Mohammad Adib berpendapat bahwa proses pembelajaran sangat terkait dengan filsafat metafisika pendidikan yang mencakup pemikiran ontologis dan antropologi (Adib, 2011, pp. 24-50). Sementara itu, Jalaludin dan kawan-kawan menambahkan bahwa pendidikan harus berorientasi pada tujuan dan juga pada hakikat manusia sebagai pembelajar (Jalaluddin \& Idi, 2002). Pendidikan juga terkait dengan filsafat epistemologi, di mana pembelajaran selalu menjunjung tinggi hakikat pengetahuan dan keabsahan dari pengetahuan yang diperoleh dengan penyelidikan dan analisa yang dalam (metode ilmiah) (Adib, 2011, pp. 24-50). Lebih lanjut, pendidikan juga ada dalam ranah filsafat aksiologi. Di dalam proses pembelajaran sangat ditekankan guna dan nilai dari pengetahuan. Capaian pembelajaran harus berdaya guna dan mendatangkan keuntungan bagi kemanusiaan (public good) dan mampu menjunjung harkat dan martabat manusia.

Hakikat pendidikan dan lembaga pendidikan ini juga merupakan bagian integral dari setiap PTKK. Lebih lagi, lembaga pendidikan teologi bukan hanya memiliki landasan yuridis dan filosofis yang mantap, tetapi juga memiliki landasan teologis yang kuat. Setiap PTKK pasti didirikan dengan dasar biblika yang kuat yang diturunkan dalam setiap visi dan misi dari setiap lembaga pendidikan tersebut. Keberadaan PTKK pasti merefleksikan keyakinan teologis pendirinya baik itu gereja, maupun kelompok masyarakat (yayasan). Hal inilah yang seharusnya memperkuat peran dan fungsi lembaga pendidikan teologi untuk mewujudkan gagasan dan cita-cita bagi kemaslahatan umat (Das Sollen).

Namun demikian, kelihatannya pandemi Covid-19 telah menginterupsi dan mendisrupsi semua lembaga pendidikan termasuk PTKK yang ada di Indonesia, bahkan di seluruh dunia. Pandemi ini telah membawa dampak global yang begitu cepat dan masif. Disrupsi 
terjadi hampir di seluruh bidang kehidupan manusia. Secara khusus, di bidang sosial, pandemi ini memaksa manusia untuk mengubah pola interaksi sosial yang selama ini dilakukan (Farah \& Nasution, 2020). Termasuk di dalamnya lembaga pendidikan sebagai salah satu arena interaksi sosial "dipaksa" untuk menerapkan metode pembelajaran yang baru karena tidak dimungkinkannya proses pembelajaran tatap muka.

Pemerintah melalui Menteri Pendidikan dan Kebudayaan memberikan rekomendasi yang tegas kepada lembaga pendidikan di semua jenjang yang berada di zona kuning, oranye dan merah untuk meniadakan pembelajaran tatap muka (Kemendikbud, 2020). Setiap lembaga pendidikan yang ada di zona ini harus mengubah metode pembelajaran dengan pembelajaran daring atau pembelajaran jarak jauh (PJJ). Pembatasan ini dilakukan untuk menghindarkan para siswa dari penularan Covid-19.

Kebijakan ini menimbulkan ekses ketidaksiapan dari lembaga pendidikan, pengajar, maupun peserta pembelajaran. Kurangnya infrastruktur dan fasilitas pembelajaran daring, tenaga pendidik yang tidak memiliki pengalaman dalam melaksanakan pembelajaran daring, serta keterbatasan finansial merupakan kesulitan-kesulitan utama yang jamak dijumpai di lembaga-lembaga pendidikan di Indonesia. Di sisi yang lain juga, pelaksanaan PJJ telah menunjukkan ketimpangan pendidikan di negara ini (Prabowo, 2020). Cita-cita untuk mencerdaskan kehidupan bangsa, tampak menjadi pekerjaan rumah yang besar bagi segenap elemen bangsa supaya pendidikan dinikmati oleh semua anak bangsa secara merata.

Kesulitan serupa juga dialami oleh PTKK yang ada di Indonesia. Pada umumnya, keberadaan PTKK ada di margin kemampuan yang setara. Pandemi ini membawa kesulitankesulitan serupa karena keterbatasan-keterbatasan yang sama yang dimiliki oleh 386
PTKK Swasta dan 10 STAKN di Indonesia (SRV4 PDDIKTI: Pangkalan Data Pendidikan Tinggi, n.d.) Berdasarkan wawancara yang dilakukan penulis kepada sejumlah ketua dan tenaga pendidik di PTKK, kendala-kendala utama yang dihadapi lembaga pendidikan teologi di masa pandemi ini berkisar pada keterbatasan koneksi internet, keterbatasan skill dalam penguasaan teknologi (IT), tidak memiliki media pembelajaran daring, keterbatasan kemampuan tenaga pendidik dalam melaksanakan PJJ, serta keterbatasan finansial (Ketua STT, 2020).

Selaras dengan wawancara ini, Hunter dalam penelitiannya menemukan bahwa keterbatasan serupa juga dihadapi oleh lembaga pendidikan teologi di Afrika, Asia, Amerika Latin, dan Eropa Timur (Hunter, 2020). Hunter menemukan bahwa pandemi Covid-19 telah mendatangkan kesulitan yang berkaitan dengan permasalahan kemanusiaan, keterbatasan kemampuan dan pengalaman pendidik, dan krisis finansial ditengah-tengah krisis nasional (Hunter, 2020).

Kebijakan pemerintah untuk menghentikan sementara pembelajaran tatap muka mendatangkan persoalan yang berkaitan dengan kemanusiaan. Penerapan PJJ membuat peserta didik khususnya mahasiswa PTKK memutuskan untuk meninggalkan kampus dan kembali ke daerah mereka masing-masing. Namun demikian, dengan bermacam-macam kesulitan yang dihadapi, tidak semua mahasiswa bisa pulang ke daerah masing-masing. Salah satu ketua Sekolah Tinggi Teologi di Jawa Tengah menyebutkan bahwa mahasiswa yang tidak bisa pulang menjadi seperti "pengungsi" yang mengharuskan sekolah tersebut untuk menyediakan berbagai keperluan mahasiswa yang tinggal di kampus tersebut (B, 2020)

Dalam kondisi keterbatasan finansial karena pemasukan yang menurun, kampus tidak memiliki pilihan untuk tidak menolong mahasiswa dengan pertimbangan kemanusiaan. Dalam situasi pandemi ini, pada umumnya 
pemasukan keuangan kampus mengalami penurunan. Krisis ekonomi membawa dampak domino yang saling memiliki keterkaitan. Kemampuan finansial keluarga mahasiswa mempengaruhi pembayaran uang kuliah mahasiswa. Sumber-sumber eksternal dari kampus juga mengalami penurunan. Di beberapa kasus, gereja yang menjadi “donor" bagi kampus juga mengalami dampak finansial. Tidak dilaksanakannya ibadah tatap muka membuat persembahan yang diterima gereja juga berkurang (Hunter, 2020). Bukan hanya itu, sekolah-sekolah yang mendapatkan dukungan dari luar negeri juga tidak luput dari imbas krisis keuangan. Krisis ekonomi global telah mempengaruhi donasi internasional untuk PTKK di Indonesia. Kesulitan finansial adalah persoalan yang juga dihadapi oleh lembagalembaga pendidikan teologi di Indonesia.

Berdasarkan latar belakang tersebut di atas, penulis akan berusaha menjawab beberapa pertanyaan penelitian sebagai berikut: Bagaimanakah seharusnya lembaga pendidikan teologi menjalankan peran transformatif bagi para peserta didiknya di tengah pandemi ini? Pola pikir filosofis seperti apakah yang seharusnya dimiliki oleh lembaga pendidikan tinggi teologi ketika menghadapi situasi ini? kajian di dalam penulisan ini berusaha untuk memberikan paradigma baru berkaitan dengan pandemi Covid-19 dari pendekatan filosofis pendidikan transformasional. Setiap kesulitan dan tantangan yang sekarang sedang dihadapi oleh lembaga pendidikan teologi dapat dilihat sebagai "pengalaman ketakmalaran" yang jika dilihat dengan benar justru dapat menjadi "kesempatan belajar" yang berguna untuk meningkatkan kapasitas tenaga pendidikan dan peserta didik.

\section{METODE}

Penelitian ini memakai metode kualitatif. Pendekatan penelitian ini menggunakan studi pustaka untuk mendeskripsikan peran pendidikan teologi sebagai agen transformasi dan filosofi pendidikan transformasional. Tinjauan pustaka sebagai metodologi untuk melakukan penelitian dan menawarkan gambaran umum tentang berbagai jenis tinjauan, serta beberapa pedoman tentang bagaimana melakukan dan mengevaluasi (Snyder, 2019). Tinjauan pustaka berbasis konten tradisional dengan mengekstrak informasi kuantitatif dari jaringan bibliografi untuk mendeteksi topik yang muncul (Strozzi et al., 2017). Sumber data yang diperoleh dari literatur-literatur yang relevan seperti buku, jurnal atau artikel ilmiah yang terkait dengan topik yang dipilih (Putri, 2019).

\section{HASIL DAN PEMBAHASAN}

\section{Pendidikan Teologi Sebagai Proses Transformasi}

Kata "transformasi" semakin sering digunakan di dalam diskursus tentang pendidikan dewasa ini. Kosakata, istilah dan konsep tentang pendidikan transformasional sangat sering dijumpai juga di dalam penelitian-penelitian pendidikan. Dalam filsafat pendidikan, pragmatis, fenomenologis, neo-Aristotelian dan postmodern, pendekatan pendidikan transformasional menjadi salah satu topik yang dibahas (Yacek \& Ijaz, 2020, p. 2).

Di Barat, terdapat nama-nama pemikir yang mengusung gagasan tentang pendidikan transformasional. Istilah "Bildungsprozesse" dalam diskusi tentang konsep pendidikan transformasional dipelopori oleh para pendidik Jerman seperti Kokemohr (2007, pp. 13-68) dan Koller (2012) Istilah tersebut menjelaskan tentang pengalaman dalam proses belajar yang dialami oleh peserta didik. Di belahan dunia yang lain, nama-nama filsuf Anglo - Amerika seperti Andrea English (2013); Higgins (2011); dan Jackson (1986) sering menjadi rujukan terhadap kajian seputar model pembelajaran transformasional yang memberikan titik berat pada pengalaman perubahan dalam proses pendidikan yang dijalani.

Hans-Christoph Koller menjelaskan bah- 
wa pengalaman dibentuk oleh berbagai wawasan yang saling berinteraksi untuk membentuk lingkungan sosial pembelajar (Koller, 2011). Bentuk-bentuk pengalaman ini bersamasama membangun "babitus" pembelajar yang menjadi dasar pegangan dalam berpikir dan bertindak. Salah seorang pemikir kenamaan dalam konsep pendidikan transformasional adalah Jack Mezirow. Landasan filosofis pemikirannya dipengaruhi oleh beberapa filsuf terkemuka di antaranya adalah: Thomas Khun yang berkaitan dengan konsep filosofis tentang paradigma; Freire yang berkaitan dengan konsep pertumbuhan ketelitian dan kedewasaan; kemudian Habermas tentang tindakan komunikatif (lihat Calleja, 2014).

Seperti nama di dalam konsep pendidikan ini, transformasi menjadi poros dalam proses pembelajaran. Mezirow mengetengahkan konsep "Perubahan Pola Pikir Perspective Transformation" untuk menjelaskan pengalaman kebebasan dari ketergantungan ideologi yang mengungkung pembelajar (Mezirow, 1981, pp. 6-9). Mezirow meyakini bahwa perubahan pola pikir dipercepat oleh pengalaman "dilema yang membingungkan disorienting dilemma" yang memberikan ruang bagi gangguan dalam kapasitas pembelajar untuk mengembangkan aspek pengalaman tertentu yang lebih bermakna. Baginya, hadirnya berbagai kesulitan, persoalan, dan tantangan dalam proses pembelajaran yang menghadirkan kebingungan dan rasa tidak mampu justru akan membuat pembelajar memiliki kemampuan yang lebih setelah menggumuli dan berpengalaman dengan kesulitan itu. Inilah yang disebut dengan perspective transformation oleh Mezirow, di mana kesulitan dan persoalan justru dapat meningkatkan kemampuan peserta didik dan mengubah pola pikirnya.

Koller mengetengahkan istilah "perubahan wujud; trasfigurasi - re-figuration; transfiguration" untuk menjelaskan transformasi dalam proses pembelajaran (Koller, 2012, p. 18).
Dia berpendapat bahwa pendidikan transformatif melibatkan proses konfrontasi dengan pengalaman baru dalam lingkungan kognitif; persoalan-persoalan baru yang ditempatkan dalam pengalaman pembelajaran memungkinkan model interpretasi baru dalam menemukan cara-cara baru untuk terlibat di tengah-tengah dunia. Transformasi merupakan penilaian ulang, konstruksi ulang, dan penyesuaian kembali diri pembelajar dan dunia (Koller, 2012). Momen eksperimental ini akan menjadi rekonstruksi wacana yang membentuk kebiasaan pengalaman belajar.

Dalam kosakata filosofis dan psikologi moral, Yancek dan Ijaz mengangkat istilah "penarasian kembali - renarrativation" atau menuliskan ulang kisah hidup seseorang untuk menjelaskan momentum berpengalaman dengan pengalaman transformatif (Yacek \& Ijaz, 2020). Penarasian kembali terjadi ketika peserta didik berjumpa dengan nilai baru (new etbical good). Mereka menambahkan bahwa penarasian ulang melibatkan pemahaman substantivisme bahwa pendidikan transformatif tidak dapat menghindari unsur pendidikan normatif, namun normativitas ini diperoleh dari pengalaman transformatif, daripada serta merta mengambilnya dari imajinasi sosial di luar pengalaman peserta didik (Yacek \& Ijaz, 2020)

Para pemikir pendidikan transformasional menggunakan kosakata yang beragam untuk menekankan perubahan dalam pendekatan pendidikan ini. Koller menjelaskan ranah perubahan (transfiguration) harus mencakup ranah kebiasaan, keterampilan dan watak peserta didik (babitus). Dengan penekanan yang sedikit berbeda Mezirow menitikberatkan perubahan pada pola pikir atau persepsi peserta didik (perspective transformation) yang diyakini menjadi pintu gerbang bagi perubahan babitus Koller. Sedangkan Yancek dan Ijaz melihat dalam rentang yang lebih jauh dan dampak yang lebih besar terhadap dampak pendidikan transformasional. Mereka melihat bahwa pengalaman transformatif sungguh- 
sungguh dapat mengubah kisah hidup seseorang (renarrativation). Namun demikian, pada dasarnya ketiga pemikiran transformatif ini sepakat untuk memberikan ruang bagi konfrontasi dengan pengalaman baru, sebuah kebingungan dilema (disorienting dilemma), dan nilai baru (new ethical good) dalam proses belajar.

Konsep pendidikan transformasional sekarang banyak menjadi fokus bagi lembagalembaga pendidikan di seluruh dunia. Rahkesh Khurana dekan Harvard College mengatakan bahwa transformasi adalah tujuan fundamental dari institusi pendidikan. Dia berpendapat bahwa lembaga pendidikan adalah "susunan sosial - social compact" yang harus menyediakan pengalaman transformatif yang memperlengkapi setiap peserta didik menjadi pemimpin yang lebih baik di tengah-tengah masyarakat (Khurana: A Case Study | News | The Harvard Crimson, n.d.). Asia Graduate School of Theology (AGST) sebagai konsorsium Pendidikan Tinggi Injili di Asia, mendasarkan setiap program pada filosofi pendidikan transformasional. Setiap proses pembelajaran di AGST dirancang untuk mengubah pemikiran, emosi, intuisi dan pengalaman setiap peserta didik di konteks Asia (AGST Program Handbook, 1984). Mereka menegaskan bahwa pendidikan teologi harus memiliki dimensi pengalaman. Svetlana Khobnya, dosen di Nazarene Theological College (NTC) di Manchester, Inggris menambahkan bahwa lembaga pendidikan teologi di GKN harus mengizinkan peserta didik untuk mendapatkan lebih dari pengetahuan mentah saja dalam proses pembelajaran (Khobnya, 2017) Ia menambahkan bahwa untuk mengubah peserta didik dan menyiapkan mereka menjadi agen pembaharu, NTC mengombinasikan pembelajaran dengan mempraktikkan iman Kristen sebagai sarana penerapan prinsip-prinsip yang dipelajari.

Pendidikan transformasional idealnya menjadi corak pendidikan teologi. Penyelenggaraan pendidikan teologi bukan hanya aktivitas penyampaian informasi, melainkan proses mengubah kehidupan. Hal ini juga dikemukakan oleh C. V. Jacob yang mengatakan bahwa teologi sebagai disiplin ilmu yang lebih dari sekumpulan teori; proses pembelajaran di dalam lembaga pendidikan teologi menuntut refleksi, orientasi pada transformasi dan memfasilitasi tindakan transformatif baik dalam level individu, komunitas iman, atau dunia yang lebih luas (Jacob, 2010, p. 2). Tugas transformasi pendidikan teologi harus menjangkau setidaknya tiga aspek kehidupan seseorang: akademik (intelektual), pribadi (moral \& spiritual) dan pelayanan/misiologis (kejuruan) (Hidrowoh, 2018). Untuk menjadikan pendidikan transformasional, pendidikan harus dipraktikkan melalui realitas kehidupan manusia atau melalui keterlibatan aktif dalam misi bagi dunia.

\section{Pandemi Sebagai Pengalaman Ketakmalaran}

Kata "ketakmalaran" berasal dari kata "malar" yang artinya terus-menerus (terjadi, ada); tetap tidak berubah (Poerwadarminta, 1991). Ketakmalaran adalah bentuk negasi dari kata malar yang bisa diartikan sebagai ketidakberlangsungan atau ketidakberlanjutan. Di dalam beberapa diskursus yang berbeda, istilah ini juga sering digunakan sebagai sebuah konsep dari sang pemikir misalnya ketakmalaran Mohorevicic, ketakmalaran Conrad, ketakmalaran Gutenberg, atau dalam konteks ilmu fisika terdapat istilah ketakmalaran serapan (Arti Kata Ketakmalaran Mohorevicic Dalam Kamus Indonesia-Inggris. Terjemahan Dari Bahasa Indonesia Ke Bahasa Inggris - Kamus Lengkap Online Semua Bahasa, n.d.). Di dalam artikel ini, istilah "ketakmalaran" merujuk pada konsep "discontinuity" yang digunakan oleh English dalam bukunya Discontinuity in Learning: Dewey, Herbart and Education as Transformation (English, 2013). English merumuskan konsep filosofis pembelajaran dengan menempatkan masalah, perjuangan, kesulitan, kekecewaan, penderitaan, dan berbagai "pengalaman negatif" sebagai 
interupsi atau ketakmalaran dalam proses pembelajaran. Ketakmalaran ini kemudian menjadi "ruang" hadirnya pengalaman menggumuli masalah yang mengganggu proses belajar mengajar. Ketika hal tersebut terjadi, pembelajaran yang sebenarnya justru sedang terjadi. Pengalaman pergulatan dengan kesulitan ini melibatkan pertemuan dengan sesuatu yang baru, seperti konsep baru, perspektif yang berbeda, atau aktivitas asing yang coba diketahui dan dipahami oleh peserta pembelajaran. Inilah pembelajaran yang berorientasi pada pengalaman menurut English.

Mezirow menggunakan istilah "dilema yang membingungkan - disorientating dilemma" untuk menggambarkan ketakmalaran dalam proses pembelajaran (Mezirow, 1981). Dia percaya bahwa krisis hidup atau transisi besar memicu "dilema yang membingungkan" yang menuntun pembelajar kepada transformasi pribadi, yang kemudian menjadi sebuah transformasi pola pikir - perspective transformation. Dilema semacam ini tidak dapat diselesaikan hanya dengan memperoleh lebih banyak informasi, meningkatkan keterampilan untuk memecahkan masalah, atau menambah kompetensi seseorang, namun melalui proses pembelajaran di mana subjek pembelajar bergerak dari cara berpikir yang tidak diuji ke cara reflektif yang lebih teruji dan kritis (Calleja, 2014). Dalam hal ini, ketika seorang individu menyadari bahwa pola-pola persepsi lama tidak lagi relevan, disorientasi seperti itu akan menggerakkan pembelajar untuk mengadopsi cara-cara baru atau untuk mengintegrasikan pola-pola lama dan baru (Imel, 1998)

Interupsi yang muncul dalam proses pembelajaran mungkin menyebabkan tujuan dan harapan kelas yang terputus atau terhenti. Pada momentum ini ketakmalaran seolah-olah membuat peserta didik tidak mendapatkan apaapa dalam proses pembelajaran. Akan timbul juga persoalan koordinasi antara tujuan yang ditetapkan dan ekspektasi kelas dengan realitas lingkungan tempat peserta belajar berada.
Namun sebaliknya, menurut English, ketika ketakmalaran terjadi, justru proses belajar "menerima sesuatu dari dunia" yang sebelumnya tidak diperhitungkan (English, 2013). Momen ini di satu sisi akan memberikan kejutan, namun di sisi lain, hal ini akan memaksa peserta belajar untuk merenungkan keterbatasan pengetahuan dan kemampuannya. Ketakmalaran akan menghadirkan pengalaman reflektif untuk meningkatkan kapasitas. English bahkan mencirikan pengalaman reflektif seperti keterasingan dari diri dan lingkungan seseorang (English, 2013).

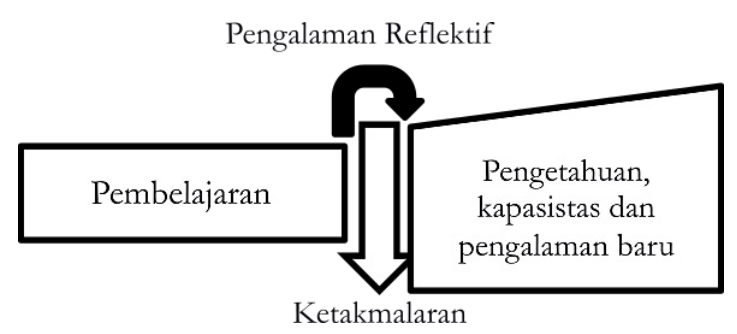

Gambar 1. Ketakmalaran dalam proses pembelajaran

Pengalaman menghadapi ketakmalaran dalam proses belajar akan memberi ruang bagi transformasi untuk beroperasi. Meskipun "pengalaman negatif" ini pada awalnya mungkin tampak menghadirkan hambatan bagi proses pembelajaran, namun ini secara bersamaan juga dapat memicu langkah pertama yang penting dalam proses transformasi. Melalui pengalaman ini, cakrawala harapan peserta belajar dinegasikan, disusun kembali dan diubah (Yacek \& Ijaz, 2020). Lebih lanjut, English berpendapat bahwa para peserta dalam proses pembelajaran harus memilih untuk mengubah ketakmalaran yang muncul menjadi masalah yang dapat dipecahkan, dan berkomitmen untuk merevisi konstelasi kebiasaan, harapan, dan cara berpikir yang menyebabkan masalah tersebut (English, 2013). Konsep transformatif English sejalan dengan pemikiran Koller dalam konsepnya tentang proses pendidikan trans- 
formatif (transformatorische Bildungsprozesse) (Koller, 2012). Menurutnya kesulitan yang secara berkala mengganggu jalannya pembelajaran, juga akan mengungkapkan ketidakcukupan dalam cakrawala pengalaman yang ada. Dalam pengertian "alam horizontal", Koller mengamati bahwa pengalaman ini akan merekonstruksi cakrawala dan bentuk kebiasaan peserta belajar.

Gagasan ketakmalaran dalam diskursus hermeneutika juga digunakan oleh Günther Buck. Dia menggunakan istilah "kekecewaan" (Enttäuschung) dan pengalaman negatif untuk menjelaskan dinamika transformasi (Buck, 1981). Dalam pandangan ini, jalannya pengalaman secara berkala diinterupsi oleh "krisis," di mana ekspektasi dan antisipasi pengalaman dikecewakan oleh beberapa kejadian problematik. Baginya, kekecewaan itu sekaligus mengawali pembentukan cakrawala baru yang lebih komprehensif yang mampu memaknai unsur-unsur problematik yang hadir.

Charles Taylor mengetengahkan kata "tekanan - pressure" untuk mengakui hadirnya gangguan yang memiliki peran sebagai pembentuk ketakmalaran oleh perspektif formalistis dalam pengalaman transformatif (Taylor, 2016, p. 180). Pemahaman Taylor sangat dekat dengan konsep Mezirow dan English dalam menempatkan pemberi interupsi dan elemen pengalaman yang akhirnya akan memimpin pada pengalaman transformatif. Dia juga menekankan peran aktif peserta didik dalam menanggapi hal-hal asing yang mengganggu proses pembelajaran.

\section{Perubahan Paradigma bagi Pendidikan Tinggi Teologi di Indonesia}

Berdasarkan kerangka berpikir pendidikan transformatif, pengalaman problematik akibat pandemi Covid-19 juga dapat dilihat sebagai momen ketakmalaran dalam pendidikan teologi di Indonesia. "Pengalaman negatif" ini bisa menjadi momen "keke- cewaan" dalam proses pembelajaran yang telah disiapkan sebelumnya. Menurut wawancara dengan beberapa ketua dan dosen lembaga teologi, pandemi tersebut telah membawa kekacauan jadwal dan semua tujuan yang telah ditetapkan sebelumnya (Ketua STT, 2020). Secara umum PTKK di Indonesia juga bergumul dengan "dilema yang membingungkan" yang ditimbulkan oleh merebaknya virus novel corona.

PTKK di Indonesia seperti berbagai lembaga pendidikan di seluruh dunia sekarang menghadapi pengalaman ketakmalaran dalam kegiatan belajar mengajar. Dalam interaksi dengan kesulitan ini pendidikan teologi sedang "menerima sesuatu dari dunia" yang tidak diperhitungkan sebelumnya. Momen-momen tersebut akan memaksa PTKK melakukan refleksi atas keterbatasan pengetahuan dan kemampuan (pengalaman reflektif) yang dimiliki. Lembaga pendidikan teologi harus melihat pandemi ini sebagai Bildungsprozesse untuk mengarah pada transformasi perspektif dan untuk meningkatkan kemampuan dan kecakapan. Lembaga pendidikan teologi harus mengganti lensa untuk melihat gangguan ini dengan perspektif yang baru.

Pengalaman menghadapi ketakmalaran dalam pendidikan teologi menjadi cara untuk memperluas cakrawala dan merekonstruksi bentuk kebiasaan baik pendidik maupun peserta didik. Hasil dari praktik pendidikan adalah bahwa pendekatan transformatif untuk pengajaran dan pembelajaran secara teoritis dapat diterapkan di seluruh kurikulum, dan pengalaman transformatif dapat diperoleh di hampir semua konteks kurikuler yang mengupayakan bentuk pembelajaran yang lebih mendalam. Pandemi Covid-19 bisa menjadi momen perubahan sebagai respons terhadap kritik bahwa pendidikan teologi telah menjadi "kemewahan akademis" dari elit intelektual gereja, daripada tugas misiologis (Athyal, 2003, p. 51). Pengalaman ini bisa menjadi waktu yang tepat untuk memberikan kesempatan mengait- 
kan pendidikan teologi dengan masalah nyata masyarakat sekitar. Teologi misiologis dan praktis harus menjadi perhatian pendidikan teologi saat ini. Pendidikan teologi harus memberikan ruang yang lebih luas bagi siswa untuk melibatkan pengalamannya. Proses pembelajaran seperti inilah yang diyakini dapat menolong peserta didik untuk mengembangkan keterampilan untuk menghadapi tantangan, menyarankan solusi kreatif untuk masalah dan untuk memobilisasi orang lain untuk bertindak.

Untuk meningkatkan fokus misi ini di tengah pandemi, teologi harus mengubah proses pembelajaran menjadi pelatihan dan pendampingan. Pendidikan harus membawa transformasi, yang tidak mungkin terjadi tanpa memasukkan pelatihan praktis sebagai bagian dari kurikulum. Tenaga pendidik dan peserta didik harus menjadi bagian dari pelayanan praktis seperti mereka bekerja sama selama pengalaman belajar. Momen experiential ini membantu membangun kepercayaan diri, membuat refleksi teologis yang bermakna dan juga menjadi dasar pembentukan spiritual peserta didik (Jeyaraj, 2001, p. 48).

Ketakmalaran dalam proses pembelajaran menuntut adanya adaptasi. Salah satu perubahan nyata pembelajaran di masa pandemi adalah penempatan teknologi informasi yang berbasis internet sebagai tulang punggung pelaksanaan kegiatan pedagogi (Salsabila et al., 2020). Selain memungkinkan perluasan daya jangkau, media pembelajaran daring juga memberikan ruang bagi kreativitas dan fleksibilitas dalam belajar (Herliandry et al., 2020, pp. 65-70). Kenyataan ini juga harus diikuti oleh PTKK di Indonesia dengan pembangunan infrastruktur, kecakapan dan keterampilan dosen dalam menggunakan media pembelajaran daring, serta penyusunan kurikulum yang memberikan ruang lebih bagi peserta didik untuk menggunakan internet sebagai media belajar.
Pandemi Covid-19 juga telah memberikan kemampuan baru bagi para dosen untuk melakukan pembelajaran jarak jauh, menguasai teknologi dengan lebih baik, dan lebih kreatif dalam menyajikan materi pembelajaran. Fenomena ini mendorong para tenaga pendidik dalam literasi teknologi yang memang menjadi media utama proses pembelajaran di masa pandemi (Salsabila et al., 2020, pp. 188-198) Kecakapan dan keahlian para tenaga pendidik dalam menggunakan media pembelajaran daring semakin meningkat. Aplikasi seperti Zoom, Google Meet, Moodle, Google Classroom dan lain sebagainya semakin dikuasai oleh para pendidik (Eliasaputra et al., 2020, pp. 1-22). Infrastruktur pembelajaran berbasis internet meningkat secara signifikan di berbagai lembaga teologi di Indonesia. Capaian pembelajaran (learning outcomes) dari para peserta didik kini bukan hanya dibaca di kelas dan ruang perpustakaan sempit di kampus. Namun capaian dan luaran telah menjadi content di berbagai sosial media daring maupun research bub seperti Youtube, Pinterest, Facebook, Instagram, Academia.edu, ResearchGate, dan lain sebagainya; yang telah diakses oleh ratusan, ribuan, bahkan ratusan ribu orang dari seluruh dunia (Marbun \& Nasution, 2021). Perpustakaan, jurnal, diskusi mengarah pada sistem online yang membuka peluang akses yang lebih luas.

Selain itu, pendidikan online mendapatkan tempat prioritas yang lebih tinggi karena pandemi ini. Studi jarak jauh tidak lagi tabu bagi pendidikan teologi (Saputra, 2021). Pandemi telah mengubah persepsi bahwa pembelajaran tatap muka pasti memiliki kualitas yang lebih baik daripada pembelajaran jarak jauh. Ini adalah kesempatan bagi institusi untuk merancang program jarak jauh (sesuai dengan ketentuan dan hukum yang ada) untuk para hamba Tuhan yang ingin belajar tetapi dibatasi oleh jarak dan tanggung jawab dalam pelayanan mereka. 


\section{KESIMPULAN}

Kehadiran pandemi Covid-19 menjadi pengalaman yang tidak terduga bagi PTKK di Indonesia. Di satu sisi, pandemi ini telah mendatangkan krisis dan kesulitan besar, namun di sisi lain dalam perspektif filsafat pendidikan transformasional, ketakmalaran proses pembelajaran justru menjadi kesempatan untuk bertransformasi. Peluang ini harapannya dapat dimanfaatkan PTKK dalam ranah persepsional, tetapi juga sekaligus dalam ranah praktikal. Pola pikir dan konsep dari penyelenggara pendidikan teologi harus berubah, tidak lagi melihat Covid-19 sebagai

\section{DAFTAR RUJUKAN}

Adib, H. M. (2011). Filsafat Ilmu: Ontologi, Epistemologi, Aksiologi, dan Logika Ilmu Pengetahuan. Pustaka Pelajar.

AGST Program Handbook. (1984).

Arti kata ketakmalaran Mohorevicic dalam kamus Indonesia-Inggris. Terjemahan dari bahasa Indonesia ke bahasa Inggris - Kamus lengkap online semua bahasa. (n.d.).

B, K. S. (2020). Wawancara oleh Penulis.

Buck, G. (1981). Hermeneutik und Bildung. Wilhelm Fink.

Calleja, C. (2014). Jack Mezirow's Conceptualisation of Adult Transformative Learning: A Review. Journal of Adult and Continuing Education, 20(1), 117-136. https://doi.org/10.7227/ JACE.20.1.8

Eliasaputra, M. P., Novalina, M., \& Siahaan, R. J. (2020). Tantangan Pendidikan Agama Kristen di Era Revolusi Industri 4.0 dan Pasca Kebenaran. BONAFIDE: Jurnal Teologi Dan Pendidikan Kristen, 1(1), 1-22.

English, A. (2013). Discontinuity in Learning:

Dewey, Herbart and Education as Transformation. Cambridge University Press.

Farah, B., \& Nasution, R. D. (2020). Analisis Perubahan Orientasi Pola Hidup hambatan dan musuh PTKK, tetapi ruang perubahan dalam pendidikan teologi di Indonesia. Di dalam tataran praktikal, secara singkat, transformasi di PTKK di masa maupun pasca pandemi harus bertransformasi dalam infrastruktur, keuangan dan administrasi, metode pengajaran, konten kurikulum (dari teoritis ke misiologis/praktis), serta peran/ hubungan tenaga pendidik - peserta didik. PTKK ditantang untuk mengambil langkah iman untuk rela meninggalkan "kebiasaan" yang tidak relevan, merengkuh cara-cara baru yang relevan, atau menggabungkan keduanya menjadi perpaduan alat pendidikan yang lebih efektif.

Mahasiswa Pasca Berakhirnya Masa Pandemi Covid-19. Jurnal Noken: IlmuIlmu Sosial, 5(2), 23-36.

Herliandry, L. D., Nurhasanah, N., Suban, M. E., \& Kuswanto, H. (2020). Pembelajaran pada Masa Pandemi Covid-19. JTP-Jurnal Teknologi Pendidikan, 22(1), 65-70.

Hidrowoh, J. R. (2018). Shaping The Leaders of Tomorrow: An Assessment of Intergenerational Perceptions of Leadership Traits (Issue December).

Higgins, C. (2011). The Good Life of Teaching: An Ethics of Professional Practice. John Wiley \& Sons.

Hunter, E. (2020). Responding to the COVID19 Crisis: Moving from Desperation to Hope in Theological Education. InSights Journal; ScholarLeaders, 6(1), 1-10.

Imel, S. (1998). Transformative Learning in Adulthood. ERIC Digest 200.

Indonesia, P. R. (2003). Undang-undang Republik Indonesia Nomor 20 Tahun 2003 tentang Sistem Pendidikan Nasional. Pemerintah Republik Indonesia. Jackson, P. W. (1986). The Practice of Teaching. Teachers College Press.

Jacob, C. V. (2010). The Missional Essence of Theological Education. Journal of Theological Education and Missio, 1(1), 1-8. 
Jalaluddin, \& Idi, A. (2002). Filsafat Pendidikan Manusia, Filsafat dan Pendidikan. Gaya Media Pratama.

Jeyaraj, J. (2001). Theological Education: Context and Involvement. TBT Journal, 3(1), 48.

Kemendikbud. (2020). Jika Satuan Pendidikan Sudah Memenuhi Semua Daftar Periksa dan Siap Melakukan Pembelajaran Tatap Muka. Panduan Penyelenggaraan Pembelajaran pada Tabun Ajaran dan Tabun Akademike Baru di Masa Pandemi Covid-19: Satuan Pendidikan di Zona Kuning, Oranye dan Merah Dilarang Melakukan Pembelajaran Tatap Muka.

Ketua STT. (2020). Wawancara oleh Penulis.

Khobnya, S. (2017). Education as Transformation: A Look into Nazarene Theological Education I HOLINESS TODAY. Holinesstoday.Org.

Khurana: A Case Study | News | The Harvard Crimson. (n.d.).

Kokemohr, R. (2007). Bildung als Welt-und Selbstentwurf im Fremden. Annäherungen an eine Bildungsprozesstheorie. In H.-C. Koller, $W$. Marotzki \& O. Sanders (Eds.), Bildungsprozesse und Fremdheitserfahrung: Beiträge zu einer Theorie transformatorischer Bildung. Deutscher Studien Verlag.

Koller, H. C. (2011). The Research of Transformational Education Processes: Exemplary Considerations on the Relation of the Philosophy of Education and Educational Research. European Educational Research Journal, 10(3), 375382. https://doi.org/10.2304/ eerj.2011.10.3.375

Koller, H. C. (2012). Bildung Anders Denken: Einführung in die Theorie Transformatorischer Bildungsprozesse. Kohlhammer.

Lembaga Pendidikan - Pengertian, Tujuan, Contoh, Ciri, \& Gambar. (n.d.).

Marbun, P., \& Nasution, A. F. N. (2021). Peningkatan Kualitas Pembelajaran Teologi Berbasis Teknologi Informasi
Komunikasi. Jurnal Sisfotenika, 11(1), 6779.

Mezirow, J. (1981). A Critical Theory of Adult Learning and Education. Adult Education, 32(1), 3-24. https://doi.org/ 10.1177/074171368103200101

Persell, C. H. (1979). Educations and Inequality, The Roots and Results of Stratification in America's Schools. The Free Press.

Poerwadarminta, W. (1991). Malar. In Kamus Umum Bahasa Indonesia (p. 627). Balai Pustaka.

Prabowo, H. (2020). Pandemi COVID-19 Menunjukkan Ketimpangan Pendidikan di Indonesia. Tirto.Id.

Putri, A. E. (2019). Evaluasi Program Bimbingan dan Konseling: Sebuah Studi Pustaka. Jurnal Bimbingan Konseling Indonesia, 4(2), 39-42.

Sagala, S. (2013). Etika dan Moralitas Pendidikan Peluang dan Tantangan. Kencana.

Salsabila, U. H., Sari, L. I., Lathif, K. H., Lestari, A. P., \& Ayuning, A. (2020). Peran Teknologi Dalam Pembelajaran di Masa Pandemi Covid-19. Al-Mutharahah: Jurnal Penelitian dan Kajian Sosial Keagamaan, 17(2), 188-198.

Athyal, S. (2003). The Missiological Core of Theological Education. UBS Journal, 1(2), 50-56.

Saputra, Y. N. (2021). Self-directed Learning Readiness Mahasiswa di Masa Pandemi Covid-19. KURIOS: Jurnal Teologi Dan Pendidikan Agama Kristen, 7(1), 164-177.

Snyder, H. (2019). Literature Review as a Research Methodology: An Overview and Guidelines. Journal of Business Research, 104, 333-339. https://doi.org/ 10.1016/j.jbusres.2019.07.039

SRV4 PDDIKTI: Pangkalan Data Pendidikan Tinggi. (n.d.).

Strozzi, F., Colicchia, C., Creazza, A., \& Noè, C. (2017). Literature Review on the 'Smart Factory' Concept Using Bibliometric Tools. International Journal of 
Production Research, 55(22), 6572-6591. Yacek, D., \& Ijaz, K. (2020). Education as https://doi.org/ Transformation: Formalism, Moralism 10.1080/00207543.2017.1326643 and the Substantivist Alternative. Journal Taylor, C. (2016). The Language Animal. Harvard of Philosophy of Education, 54(1), 124-145. University Press.

Tirtarahardja, U., \& Sasula, L. (2000). Pengantar https://doi.org/10.1111/1467-

Pendidikan. Rineka Cipta. 